\title{
Expository preaching from the Psalms
}

\begin{tabular}{|c|c|}
\hline $\begin{array}{l}\text { Book Title: } \\
\text { Preaching Chr } \\
\text { Psalms: Foun } \\
\text { expository se } \\
\text { Christian year }\end{array}$ & $\begin{array}{l}\text { st from the } \\
\text { ations for } \\
\text { mons in the }\end{array}$ \\
\hline Book Cover: & \\
\hline $\begin{array}{r}\text { PREAC } \\
\text { CH } \\
\text { PSA }\end{array}$ & $\begin{array}{l}\text { HING } \\
\text { IST } \\
\text { MS }\end{array}$ \\
\hline $\begin{array}{r}\text { FOUNDAT } \\
\text { EXPOSITOR } \\
\text { IN THE CHR }\end{array}$ & $\begin{array}{l}\text { ONS FOR } \\
\text { I SERMONS } \\
\text { STIAN YEAR }\end{array}$ \\
\hline $\begin{array}{r}\text { SID } \\
\text { GREID }\end{array}$ & $\begin{array}{l}\text { NEY } \\
\text { ANUS }\end{array}$ \\
\hline $\begin{array}{l}\text { Author: } \\
\text { Sidney Greida }\end{array}$ & \\
\hline $\begin{array}{l}\text { ISBN: } \\
978-0-8028-7\end{array}$ & \\
\hline $\begin{array}{l}\text { Publisher: } \\
\text { Grand Rapids } \\
\text { R514.64* } \\
\text { *Book price at t }\end{array}$ & $\begin{array}{l}\text { MI, 2016, } \\
\text { me of review }\end{array}$ \\
\hline $\begin{array}{l}\text { Review Title: } \\
\text { Expository pre } \\
\text { the Psalms }\end{array}$ & aching from \\
\hline $\begin{array}{l}\text { Reviewer: } \\
\text { Herculaas F. v }\end{array}$ & In Rooy ${ }^{1}$ \\
\hline $\begin{array}{l}\text { Affiliation: } \\
{ }^{1} \text { Faculty of Th } \\
\text { North-West U } \\
\text { Potchefstroon } \\
\text { South Africa }\end{array}$ & $\begin{array}{l}\text { ology, } \\
\text { niversity, } \\
\text { Campus, }\end{array}$ \\
\hline $\begin{array}{l}\text { Correspondin } \\
\text { Herculaas van } \\
\text { herrie.vanroo }\end{array}$ & $\begin{array}{l}\text { author: } \\
\text { Rooy, } \\
\text { @nwu.ac.za }\end{array}$ \\
\hline Read online: & \\
\hline 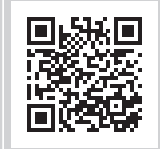 & $\begin{array}{l}\text { Scan this QR } \\
\text { code with your } \\
\text { smart phone or } \\
\text { mobile device } \\
\text { to read online. }\end{array}$ \\
\hline
\end{tabular}

This is (probably) the last volume by Sidney Greidanus, emeritus professor in preaching at the Calvin Theological Seminary in Grand Rapids, in a series on preaching Christ from the Old Testament. The previous volumes dealt with preaching Christ from the Old Testament in general with the focus on Genesis, Ecclesiastes and Daniel. This volume deals with the Psalms from the perspective of the Christian year selected for Advent, Christmas, Epiphany, the Baptism of Jesus, Transfiguration Sunday, Ash Wednesday, Lent, Palm Sunday, Good Friday, Easter, Ascension, Pentecost, Trinity Sunday and Christ the King. The Psalms were taken from The revised common lectionary. The Psalms were not meant as preaching texts, but present a good variety of the different kinds of Psalms.

In the first chapter of the book, Greidanus discusses the Psalms in general as well as the issues related to preaching from it. He follows the method outlined in the first book in the series including ten steps from text to sermon. The following chapters deal with one Psalm at a time and conclude with a 'sermon exposition'. In preaching Christ from the Psalms, he emphasises the important point that one should not read Christ back into the Psalms from the perspective of the New Testament. One should rather move from the message of a Psalm to Jesus in the New Testament.

In his approach to the Psalms Greidanus states that proper interpretation should take four dimensions into account: literary, historical, theocentric and Christocentric. He discusses the different types of Psalms, poetic devices, rhetorical structures and the literary context thereof. This section of the book, as well as the one on historical interpretation of the Psalms, offer valuable insights into the interpretation of the Psalms and would be of great value to any preacher. The theocentric and Christocentric interpretation of the Psalms is also of great value. In these sections Greidanus demonstrates that he is up to date with recent research on the Psalms. It also presents a good introduction into the Psalms and can be used by any minister wanting to preach from it.

As far as preaching from the Psalms is concerned, Greidanus regards the poetry, with their appeal to the emotions, as valuable. With regard to a preaching text, he prefers taking a whole Psalm as preaching text and proposes that one should follow the movement of each Psalm.

In the book more than 20 Psalms are discussed according to this model with an indication of how a sermon on a specific Psalm could be structured. Psalm 122 could serve as an example of this approach. The theme of Psalm 122 is 'Pray for the peace of Jerusalem' and it is the first Psalm that can be chosen for Advent. It is one of the songs of ascents. It follows on Psalm 120 and 121 with danger and violence as theme. Psalm 122 contrasts the security of Jerusalem against these dangers. In his literary interpretation, Greidanus discusses the parallelisms in this Psalm, its imagery, the repetition of keywords and its structure. In the theocentric interpretation he emphasises the function of Jerusalem as the city of the Lord. The people went to Jerusalem to praise the Lord. The Psalm is a prayer for the peace of Jerusalem. He wants to preach Christ from this Psalm by way of redemptivehistorical progression supported by New Testament references. Typology could also be used with the temple as a type of Christ entering the world and being Immanuel. He prefers the idea of redemptive-historical progression. Jesus went to the temple and predicted its destruction. After Pentecost, the temple was replaced by God's people - the church. The aim of a sermon on this Psalm would be to encourage God's people to go to the house of the Lord and to pray for peace for the church and the New Jerusalem. The structure of the Psalm is used for structuring the sermon with three sections following the three parts that can be distinguished in the Psalm (vs. 1-2 - going to Jerusalem; vs. 3-5 - Jerusalem itself; vs. 6-9 - praying for the peace of Jerusalem) and a fourth section with a New Testament perspective on the church and the New Jerusalem.

The approach of this book corresponds with traditional reformed hermeneutics, accepting the authority of the Old Testament Psalms for the New Testament church. It will be of great value to seminary students and pastors and can be recommended without any reservation.

How to cite this book review: van Rooy, H.F., 2017, 'Expository preaching from the Psalms', In die Skriflig 51(1), a2269. https://doi. org/10.4102/ids.v51i1.2269

Copyright: @ 2017. The Authors. Licensee: AOSIS. This work is licensed under the Creative Commons Attribution License. 